HortSCIENCE 26(11):1379-1381. 1991.

\title{
Orchard Floor Management Practices Influence Elemental Concentrations in Young Pecan Trees
}

William D. Goff

Department of Horticulture and Alabama Agricultural Experiment

Station, Auburn University, AL 36849

Michael G. Patterson

Department of Agronomy and Soils and Alabama Agricultural Experiment Station, Auburn University, AL 36849

\author{
Mark S. West \\ Department of Research Data Analysis and Alabama Agricultural \\ Experiment Station, Auburn University, AL 36849
}

Additional index words. weed control, nut crops

Carya illinoensis, potassium, fertilization, herbicides, tillage,

\begin{abstract}
Nutrient status of young pecan [Carya illinoensis (Wangenh.) C. Koch] trees grown under eight combinations of orchard floor management and irrigation was determined by leaf and soil analyses. Orchard floor management practices were weedyunmowed, weedy-mowed, weed control with herbicides, and weed control by disking, with trees either irrigated or nonirrigated. The element most affected by treatment was $K$. Mean leaf $K$ for the two sample years was significantly $(P<0.01)$ lower in the weedy plots $(0.56 \% \mathrm{~K})$ than in those where weeds were controlled $(0.76 \% \mathrm{~K})$, suggesting a highly competitive effect of weeds for $K$ with young pecan trees. Weed competition also suppressed leaf $\mathrm{Ca}$ and $\mathrm{Mg}$, but presence of weeds or sod resulted in higher soil $\mathrm{pH}$ and higher leaf $\mathrm{Zn}$. Leaf concentrations of $\mathrm{N}, \mathrm{P}, \mathrm{B}, \mathrm{Cu}$, and $\mathrm{Fe}$ were not significantly affected by the treatments.
\end{abstract}

In pecan, information on plant nutrition as affected by orchard floor management is limited. Worley and Carter (1973) compared grazing, clean cultivation + winter legumes, intercropping + summer cultivation, and mowed sod treatments in an orchard of

Received for publication 28 Jan. 1991. Alabama Agricultural Experiment Station Journal Series no. 11-912868P. Appreciation is expressed to Ronnie McDaniel and Emmett Carden for maintenance of the planting. The cost of publishing this paper was defrayed in part by the payment of page charges. Under postal regulations, this paper therefore must be hereby marked advertisement solely to indicate this fact. old 'Stuart' pecan trees and found treatment differences for foliar concentrations of N, P, $\mathrm{Ca}, \mathrm{Mn}$, and Zn. Smith et al. (1960) found that sod without a legume decreased leaf $\mathrm{N}$ concentrations compared to summer clean cultivation with a cool-season legume. Pecan leaf $\mathrm{N}$ concentrations using a sod with a legume were similar to summer clean cultivation with a cool-season legume. Norton (1970) reported that weed competition reduced leaf N. Gossard and Hammar (1957) reported no consistent differences in $\mathrm{N}, \mathrm{P}, \mathrm{K}, \mathrm{Ca}$, or $\mathrm{Mg}$ concentrations of pecan leaves between sod and clean cultivation. Since nutrient concentration affects growth, yield, and kernel quality in pecans (Sparks, 1989), we con- 
Table 1. Elemental concentrations and soil $\mathrm{pH}$ corresponding to planned contrasts of orchard management and irrigation treatments. Data are pooled over 2 years.

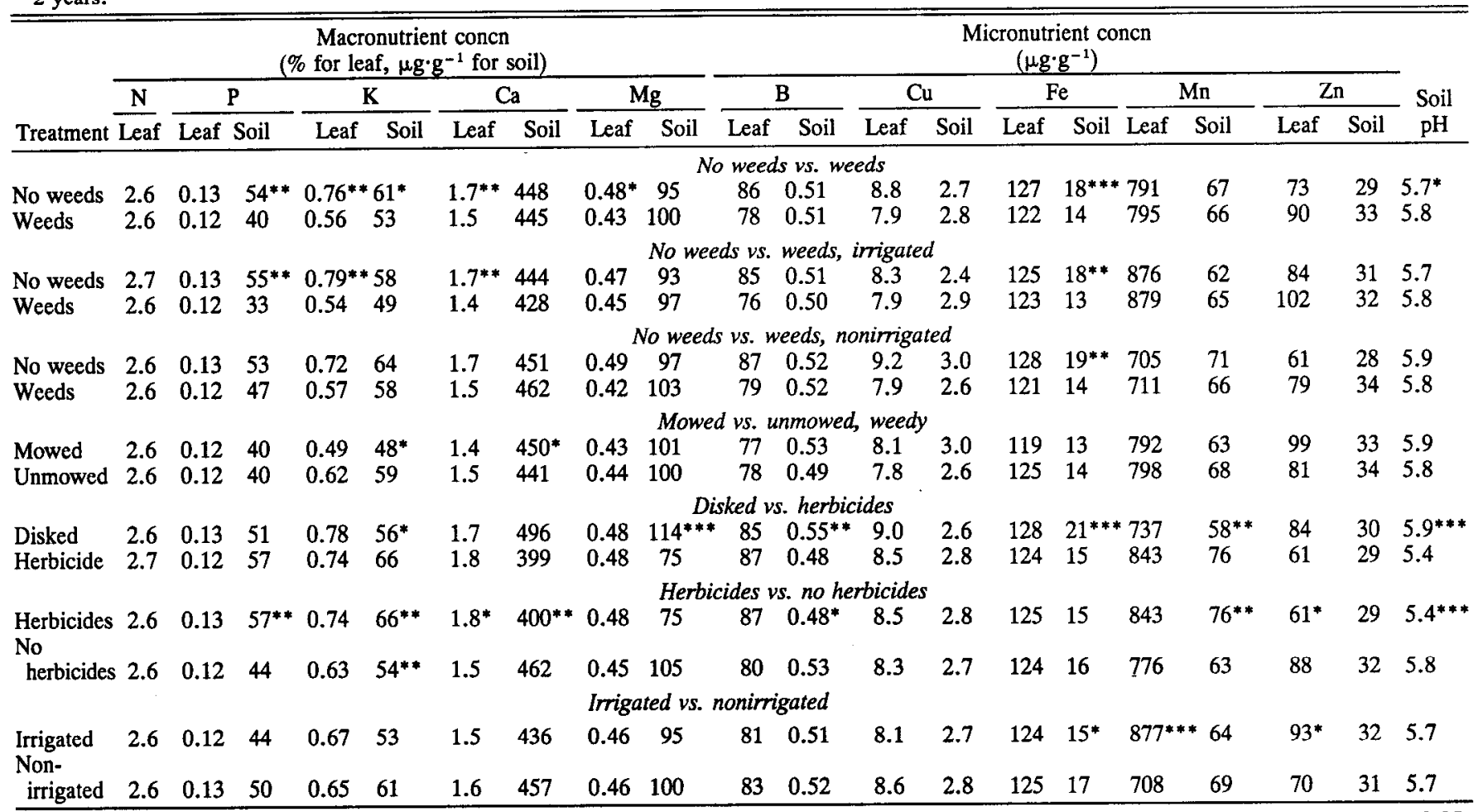

*,*****Differences for a contrast at $P=0.05,0.01$, or 0.001 , respectively. Contrasts not followed by asterisks arc not significantly different at $P=0.05$.

ducted this experiment to examine the effects of orchard floor management practices on nutrient concentrations of young pecan trees. Growth of the trees in the same experiment was reported previously (Patterson et al., 1990).

'Desirable' pecan trees planted bareroot in Feb. 1986 in a Malbis fine sandy loam (fine loamy siliceous, thermic Plinthic Paleudults) at the Gulf Coast Substation, Fairhope, Ala., were used in the experiment. Spacing was $9.1 \times 10.7 \mathrm{~m}$. The experimental area was infested with large crabgrass [Digitaria sunguinalis (L.) Scop.], common bermudagrass [ Cynodon dactylon (L.) Pers.], yellow nutsedge (Cyperus esculentus L.), pitted moming glory (Ipomoea lacunosa L.), prickly sida (Sida spinosa L.), horseweed [ Conyza canadensis (L.) Cronq.], Carolina geranium (Geranium carolinianum L.), henbit (Lumium amplexicaule L.), cutleaf evening primrose (Oenothera laciniata Hill), and tall ironweed (Veronica altissima Nutt). Moderate to high populations of large crabgrass, common bermudagrass, and yellow nutsedge were present at planting.

Lime and fertilizer were applied and incorporated before planting based on soil analysis. Postplant fertilizer and lime applications were uniformly applied to all plots based on composite leaf and soil samples taken in July to determine the following season's application, according to established recommendations (O'Barr et al., 1989).

Treatments were arranged in a split-plot design, with irrigation at two levels, irrigated or nonirrigated, assigned randomly to rows within the four main plots. The rows were split into single-tree subplots to which four orchard floor management practices (weedy-unmowed, weedy-mowed, weed control with herbicides, and weed control by disking) were assigned.

Mowing and disking were performed during the growing season on a 2- and 4-week schedule, respectively. Weed control with herbicides was with preemergence application in March of 4-(dipropylamino)-3,5-dinitrobenzenesulfonamide (oryzalin) plus 1,1'-dimethyl-4,4'-bipyridinium ion (paraquat) at 2.2 and $0.6 \mathrm{~kg}$ a.i./ha, respectively. This March application was followed with two applications of $\mathrm{N}$-(phosphonomethyl)glycine (glyphosate) at $2.2 \mathrm{~kg}$ a.i./ha during June and August and an application of 4-chloro-5(methylamino)-2-(3-(trifluoromethyl)- phenyl)$3(2 \mathrm{H})$-pyridazinone (norflurazon) at $2.7 \mathrm{~kg}$ a.i./ ha in the fall. In the second growing season after planting and thereafter, 6-chloro-N,N'diethyl-1,3,5-triazine-2,4-diamine (simazine) at $3.4 \mathrm{~kg}$ a.i./ha was added to the oryzalin + paraquat treatment. All herbicides were applied with a tractor-mounted, boom-type sprayer using compressed air $(220 \mathrm{kPa})$ as the propellant and delivering a carrier volume of 140 liters.ha ${ }^{-1}$. All weed control treatments were confined to a $3 \times 3-\mathrm{m}$ area centered on the tree.

Drip irrigation, using five emitters per tree delivering a total of 19 liters-h-l, was applied to irrigated plots according to the scheduling proposed by Daniel1 (1989). Irrigation was initiated Mar. 1986 at planting and has been maintained since that time. Other management practices, including pest control, were those normally recommended for commercial pecan orchards (Goff, 1989; McVay et al., 1990).

In July 1988, the 3rd year of treatment application, and again in July 1990, leaf samples were collected and analyzed to determine foliar elemental concentrations. The samples consisted of 50 leaflets taken from the middle of compound leaves attached to the middle of current-season's shoots of each tree. Leaves were rinsed briefly in water containing $2 \%(\mathrm{v} / \mathrm{v})$ detergent to remove surface contaminants, then again in water, and allowed to dry before analyzing. Samples were analyzed for $\mathrm{B}, \mathrm{Ca}, \mathrm{Cu}, \mathrm{Fe}, \mathrm{K}, \mathrm{Mg}, \mathrm{Mn}, \mathrm{N}$, $\mathrm{P}$, and $\mathrm{Zn}$ using a dry ashing technique (Hue and Evans, 1986). Soil samples were collected in July 1990 from within the $3 \times 3$ $\mathrm{m}$ treated area surrounding each tree to a depth of $20 \mathrm{~cm}$. These samples were analyzed for the same nutrients, except $\mathrm{N}$, and for soil $\mathrm{pH}$ using established procedures (Hue and Evans, 1986; Mehlich, 1953). Results of analyses were compiled and tested using analyses of variance and contrasts of interest selected a priori (Mize and Schultz, 1985).

The element most affected by treatment was $\mathrm{K}$ (Table 1). Where weeds were not controlled, mean $\mathrm{K}$ concentration in leaves was $0.56 \%$, which is considered deficient (O'Barr et al., 1989). This compares to a mean of $0.76 \% \mathrm{~K}$, a marginal-to-adequate leaf concentration, in the treatments where weeds were controlled by herbicides or disking. Soil K was also significantly lower $(\mathrm{P}<0.05)$ in 1990 in the plots in which weeds were not controlled. These results indicate that weeds are highly competitive for $\mathrm{K}$ with young pecans.

Leaf $\mathrm{Ca}$ was higher in trees that were in herbicide-treated plots $(\mathrm{P}<0.05)$. The leaf $\mathrm{Ca}$ concentration for the two years from herbicide-treated trees was $1.8 \%$, compared to $1.5 \%$ in trees receiving no herbicides. Similarly, leaf Ca was higher in nonweedy floor 
management treatments $(1.7 \%)$ than with weedy floor management $(1.5 \%)$. In irrigated trees, weedy plots contained less leaf $\mathrm{Ca}$, averaged over the two sample years, than did plots in which weeds were controlled.

Soil Ca in 1990 was higher in the disked than the herbicide-treated plots.

Leaf $\mathrm{Zn}$ concentration was lower $(\mathrm{P}<$, $0.05)$ in the treatments where herbicides were used (Table 1). This difference was pronounced in 1990, when the leaves of trees in the herbicide-treated plots had $\mathrm{Zn}$ concentrations of $88 \mu \mathrm{g} \cdot \mathrm{g}^{-1}$ compared to $124 \mu \mathrm{g} \cdot \mathrm{g}^{-1}$ in the trees where no herbicides were applied. As Zn deficiency became apparent, a program (O'Barr et al., 1989) of foliar application combined with soil application was initiated, which subsequently corrected the problem.

Leaf concentrations of $\mathrm{P}$ were not significantly altered by treatments (Table 1). Soil $\mathrm{P}$ in 1990, however, was lower $(\mathrm{P}<0.01)$ in the weedy plots, and the separation into a contrast of weeds vs. no weeds in irrigated plots showed that soil $\mathrm{P}$ was significantly lowered $(\mathrm{P}<0.01)$ when weeds were present under irrigation.

Leaves of irrigated trees contained higher $(\mathrm{P}<0.001) \mathrm{Mn}$ concentrations than those of the controls (Table 1). Soil Mn was higher in the areas that received herbicides than in all areas that received no herbicides $(\mathrm{P}<$ $0.05)$ or in disked areas $(\mathrm{P}<0.05)$.

Soil $\mathrm{pH}$ was significantly lower $(\mathrm{P}<0.05)$ in 1990 in the plots where weeds were controlled, but the difference was only $0.16 \mathrm{pH}$ units (Table 1). Herbicides lowered $\mathrm{pH}$, compared to the nonherbicide and disked treatments $(\mathrm{P}<0.001)$. Soil $\mathrm{pH}$ was negatively related to $\mathrm{Mn}$; thus, as $\mathrm{pH}$ decreased in the herbicide-treated plots, soil Mn increased.

Leaf concentrations of $\mathrm{N}, \mathrm{P}, \mathrm{Mg}, \mathrm{B}, \mathrm{Cu}$, and $\mathrm{Fe}$ were not significantly affected by the treatments (Table 1.) Lack of treatment effects on leaf $\mathrm{N}$ differs from some previous reports (Norton, 1970; Smith et al., 1960).

Orchard floor management and weed control can significantly alter nutritional status of young pecan trees, and a fertilization program adjusted according to the orchard management practice may be necessary. Particularly, K, Zn, $\mathrm{Ca}$, and soil $\mathrm{pH}$ were affected. Weed competition reduced uptake of $\mathrm{K}$ and $\mathrm{Ca}$, but, conversely, the presence of weeds and sod increased soil $\mathrm{pH}$ and leaf $\mathrm{Zn}$.

Weed competition reduces pecan tree growth (Patterson et al., 1990); therefore, weed control is necessary for optimum growth and early production of fruit-bearing surface. Weed control using herbicides may induce $\mathrm{Zn}$ shortages, requiring additional soil- or foliar-applied $\mathrm{Zn}$. Soil $\mathrm{pH}$ may also be lowered when the orchard is disked or when a herbicide program is used and may require additional lime or the use of nonacidifying fertilizers, such as calcium nitrate or nitrate of soda-potash, to maintain optimum $\mathrm{pH}$ (Sparks, 1977).

\section{Literature Cited}

Daniell J.W. 1989. Irrigation, p. 73-86. In: W.D. Goff, J.R. McVay, and W.S. Gazaway (eds.).
Pecan production in the Southeast...a guide for growers. Alabama Coop. Ext. Serv., Auburn Univ.

Goff, W.D. 1989. Pecan production. Alabama Coop. Ext. Serv. Circ. ANR-54, Auburn Univ. Gossard, A.C. and H.E. Hammar. 1957. Differential potassium fertilization of pecan trees combined with summer cultivation and sod systems of orchard management. Proc. Southeast Pecan Growers Assn. 50:51-60.

Hue, N.V. and C.E. Evans. 1986. Procedures used for soil and plant analysis by the Auburn Univ. soil testing laboratory. Dept. of Agron. \& Soils, Auburn Univ. Dept. Series 106.

McVay, J.R., W.S.- Gazaway, and M.G. Patterson. 1990. Commercial pecan insect. disease. and weed control recommendations. Alabama Coop. Ext. Serv. Circ. ANR-27, Auburn Univ.

Mehlich, A. 1953. Determinations of $\mathrm{P}, \mathrm{Ca}, \mathrm{Mg}$, $\mathrm{K}$, Na, and $\mathrm{NH}$, by North Carolina soil testing laboratories. North Carolina Dept. of Agr.,. Raleigh.

Mize, C.W. and R.C. Schultz. 1985. Comparing treatment means correctly and appropriately. Can. J. For. Res. 15:1142-1148.

Norton, J.A. 1970. Chemical weed control in bearing and nonbearing pecan (Carya illinoensis (Wang.) K. Koch) orchards. Diss. Abstr.

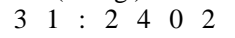

O'Barr, R.D., M. Smith, G. Taylor, and W.D. Goff. 1989. Pecan nutrition, p. 61-72. In: W.D. Goff, J.R. McVay, and W.S. Gazaway (eds.). Pecan production in the Southeast...a guide for growers. Alabama Coop. Ext. Serv., Auburn Univ.

Patterson, M.G., G. Wehtje, and W.D. Goff. 1990. Effects of weed control practices and irrigation on the growth of young pecans. Weed Technol. 4(4):892-894.

Smith, C.L., O.W. Harris, and H.E. Hammar. 1960. Comparative effects of clean cultivation and sod on tree growth, yield, nut quality, and leaf composition of pecan. Proc. Amer. Soc. Hort. Sci. 75:313-321.

Sparks, D. 1977. Soil $\mathrm{pH}$ and the pecan-A review. Pecan South 4(1):16-21.

Sparks, D. 1989. Pecan nutrition-A review. Proc. Southeast Pecan Growers Assn. 82:101-122.

Worley, R.E. and R.L. Carter. 1973. Effect of four management systems on parameters associated with growth and yield of pecan. J. Amer. Soc. Hort. Sci. 98:541-546. 